sadlenly suppressing the dietetic use of opium in Inclia ammgst a people long habituated to it. What will they substitute for it! So long as mankind are in such imperfect urmony with their environment-- so long as there are of hunger, misery, disease and want-men and women, Thether wetched or pampered, will have recourse to some intosicating drug to obtain temporary oblivion, temporary dulling of the sensibilities to misery or temporary elevatin to a sense of well-being unwarranted by the actual circumstances. Human nature is very much the same in India sa it is in England and it is vain to hope that they will not do 30. It is happening now under our very eyes. Let those who (b) wht this read the report of the Commissioner of Excise for Bengal for 1893.91. He there shows that in some districts the bigh price to which opium has been raised with the object of limiting its consumption is driving the people to ganja and in other districts to spirits. It was inevitable and the ineritable invariably happens. It may not be generally known that some three-fourths of the people of India are debarred from the use of alcohol either by reljgion or caste, and there is Eittle doubt that the dietetic use of opium as a substitute for spirits or wine receired a great impetus by the Islamic proaibition of wine at the time of the Mussulman conquest of india. It is the great merit of the Mahomedan religion that keeps two hundred millions of the human race sober. Is the English occupation of India destined to be signalised by the prohibition of opium and the relapse of the veople into habits of drunkenness? What is th that is debauching the poor, overworked and underpaid office clerk and the Calcutta baboo who, under the influence of Western ideas, has broken through the trammels of caste? is it opium? No; it is brandy and the cheap liquors imported from England and sold without let or hindrance everyThere in the bazaars. Is this the beginning of a reformation of morals? or is it to be done by an increased consumption of ganja!--oanja, which grows wild in many districts ; ganja, which infuriates, which excites to acute mania and the commission of violent crimes ; which is the cause of those wholesale murders known as "running amok," which takes the place of alcohol in Indian asylum records, which accounts alone for one-third of the admissions ${ }^{1}$ and fills them with dangerous and untrustworthy inmates.

If it is to be opium, alcohol or ganja-let me say it with all the solemnity which words can give it and which my sense of the gravity and knowledge of the issues in question demand -if it is to be opium, alcohol or ganja a thousand times let it be opium. I am, sirs, yours truly, A. Crombie, M.D.

Surgeon-Lieutenant-C Jlonel, Surgen-Superintendent, European General Hospital, Calcutta.

\section{"INFECTIOUS DISEASES IN BRADFORD."} To the Editors of THE LANCET.

SIRS,- Your annotation under the above title which appeared in THE LANCET of Aug. 26th will convey to the public an erroneous impression as to the sanitary condition of the town, and for this reason I must ask the favour of a ahort paragraph by way of explanation.

During last May, when it was seen that the section of the TeverHospital which was specially constructed for the isolation of small-pox would not afford sufficient accommodation for the increasing number of cases, it was decided to devote the whole of the hospital (containing about 200 beds) exinsirely to the isolation and treatment of this disease and to build a new temporary hospital on the other side of the cown for the scarlet ferer cases, which at that time were fer in number. Unfortunately at the commencement of July a large increase in the number of scarlet fever cases occurred. This epidemic was caused by the consumption of infected milk - a circumstance which no sanitary anthority could foresee, much less provide for. The new jospital was, in consequence, soon filled with scarlet fever ratients, and others had to be treated at home; but the incidence of this milk epidemic was not upon the poor popuation, as one would gather from your annotation, but upon the well-to-do and the rich, who possessed means of isolation at their own homes and who had no desire to avail themselves of the use of the hospital ; in fact, most of the patients dritted were servants from these infected houses. There

The figures for 1890 were-total admissions to the asylums of Lowe 3 ngal, 221 ; of these 66 were ganja-smokers, 2 opium.eaters and 7 are at the present time in Bradford about 270 beds for the isolation and treatment of infectious diseases, a proportion of beds to population that is not surpassed by any town in the country. I therefore cannot accept your statement that "the provision of hospital accommodation has been greatly neglected." With regard to your remark that "small-pox has been more severe in Bradford than in any other town in the kingdom,"'I have to refer you to the weekly return of the notification of infectious diseases issued by the Local Government Board. A glance at this will at once show you that the statement is untrue and that many towns have had small-pox more severely than Bradford. The question as to whether the hospital has been the means of disseminating small-pox is a matter of opinion. I can merely say that a few years ago the site of the hospital was quite satisfactory, the buildings being situated on a hill, with very few habitations in the immediate locality; but during the last three years the builder has been hard at work and new streets have ciept up very close to the hospital on the west side. However, on the north and east sides the corporation has purchased a large tract of land and has effectually stopped the further building of houses.

In the matter of water-supply Bradford has this year, in common with many large towns, passed through a period of anxiety, and the Waterworks Committee felt it their duty to issue a notice asking people to exercise economy and not to wilfully waste water. I enclose a copy of this notice, and beg you to observe that no such terror as "threatening with penalties" is mentioned. Trusting that you will insert this letter, I am, Sirs, yours truly,

Bradford, Aug. 29th, 1893. W. ARNolo Evans, M.D. Lond. Medical Officer of Health.

\section{TUBERCLES IN THE CORPUS STRIATUM A CAUSE OF PYREXIA.}

7o the Editors of $\mathrm{TH} \mathrm{HANCHT}$.

Sirs,-Lesions of the corpus striatum may possibly cause pyrexia, but the case recorded by Dr. Stevens in THE LANCET of Aug. 26th cannot be said to furnish very strong evidence in support of that possibility. Had there been persistent high temperature the presence of tubercles in the corpus striatum would bave been interesting, and, perhaps with some reason, might have been considered to hare been connected with the pyrexia. Marked rise of temperature is, however, so common at the termination of cases of tuberculous meningitis that it would be unreasonable to suppose that tubercles are present in the corpora striata in every instance ; but that they are unable to materially affect the temperature until death approaches. The rise of temperature is probably merely a sign of the coming end, the beat, respiratory and cardiac centres failing in succession. In death from cerebral disease one centre may fail before another-e.g., I have seen a case of death from cerebral tumour in which the respiration stopped two minutes before the pulse. Curiously enough, a disease in which the heat regulation centres most frequentl fail as death approaches is one of the abdomen and not of the brain. In children who are dying from diarrhœe the temperature almost invariably rises to a considerable height a few hours before the end and may continue to rise after death. In this disease the cerebral centres are probably paralysed by the action of poisons absorbed from the alimentary canal. In a recent letter to THE LANCET ${ }^{1}$ I suggested that death in tuberculous meningitis was also brought about by the action of poisons, since in many instances there is, post mortem, no evidence to show that there has been sufficient damage to the brain to cause death.-I am, Sirs, yours truly,

Oakfield-road, Clifton, Sept. 5th, 1893 . THEODORE Fisher.

\section{"APYREXIAL INFLUENZA."}

\section{To the Editors of THE LANCET.}

SrRs,--Your leading article of Aug. 12th, in which you refer to Dr. Wilks' letter to you upon this subject in a previous issue, emboldens me to mention very briefly another case of influenza in which decided nerve symptoms occurred without a previous febrile state. I must first state that in January, 1890, whilst attending several patients attacked by influenza, 1 suffered for four days from sudden "febricula", and pains in various muscles. This I believed to be influenza, 